\title{
Streptomyces lunalinharesii sp. nov., a chitinolytic streptomycete isolated from cerrado soil in Brazil
}

\author{
Rodrigo Fonseca de Souza, ${ }^{1}$ Rosalie Reed Rodrigues Coelho, ${ }^{1}$ \\ Andrew Macrae, ${ }^{1}$ Rosangela Maria Araújo Soares, ${ }^{1}$ Débora da Costa \\ Morato Nery, ${ }^{1}$ Luzia Teixeira de Azevedo Soares Semêdo, ${ }^{1,2}$ \\ Celuta Sales Alviano ${ }^{1}$ and Rosana Canuto Gomes ${ }^{1,2}$
}

Correspondence

Rodrigo Fonseca de Souza rsouza.rlk@terra.com.br

\author{
${ }^{1}$ Instituto de Microbiologia Prof. Paulo de Góes, Universidade do Brasil, UFRJ, CCS, Bloco I, Ilha do \\ Fundão, Rio de Janeiro 21941-590, Brazil \\ ${ }^{2}$ Centro de Ciências e da Saúde, Universidade Severino Sombra, USS, Av. Expedicionário Oswaldo \\ de Almeida Ramos -280, Centro, Vassouras, Rio de Janeiro 27700-000, Brazil
}

\begin{abstract}
A novel chitinolytic actinomycete isolated from a Brazilian cerrado soil, designated strain RCQ $1071^{\top}$, was assigned to the genus Streptomyces on the basis of chemical and morphological characteristics. The almost-complete nucleotide sequence of the 16S rRNA gene of strain RCQ $1071^{\top}$ was determined and also placed this strain in the genus Streptomyces. Phylogenetic analyses of $16 \mathrm{~S}$ rRNA gene sequences showed that strain RCQ $1071^{\top}$ formed a long branch in a group related to Streptomyces albulus, sharing approximately $98 \%$ sequence similarity. Levels of DNA-DNA relatedness between strain RCQ $1071^{\top}$ and members of this group, namely S. albulus DSM 40492 ${ }^{\top}$, Streptomyces noursei DSM $40635^{\top}$ and Streptomyces yunnanensis DSM $41793^{\top}$, were $38.3,27.8$ and $46 \%$, respectively, strongly indicating that strain RCQ $1071^{\top}$ was not a member of any of these species. The relatively long branch length within a stable clade together with the phenotypic data strongly supported that strain RCQ1071 ${ }^{\top}$ represented a novel species. Based on the combination of physiological, phylogenetic and genomic data, strain RCQ $1071^{\top}$ is suggested to represent a novel species of the genus Streptomyces, for which the name Streptomyces lunalinharesii sp. nov. is proposed. The type strain is RCQ $1071^{\top}\left(=\right.$ ATCC BAA $-1231^{\top}=$ CIP $108852^{\top}=$ DSM $\left.41876^{\top}\right)$.
\end{abstract}

Actinomycetes are filamentous, Gram-positive bacteria widely distributed in terrestrial environments, where they are responsible for the degradation and recycling of many natural biopolymers. Together with their broad metabolic capabilities and their ability to produce pigments, antibiotics and hydrolytic enzymes, this makes them a fascinating group to study and to be employed in biotechnological applications. The genus Streptomyces remains a focus for research, not only because its members are still the most promising source of commercially significant compounds, but also because current molecular biology methods are having an increasing impact on conventional systematics of streptomycetes (Williams et al., 1983a, b; Goodfellow et al., 1992; Huang et al., 2004). Streptomycetes represent a considerable proportion of actinomycete communities in soils and are intrinsically linked with soil quality and function. Our

The GenBank/EMBL/DDBJ accession number for the $16 \mathrm{~S}$ rRNA gene sequence of strain RCQ $1071^{\top}$ is DQ094838.

A table detailing differential phenotypic properties between strain RCQ $1071^{\top}$ and chitinolytic Streptomyces species is available as supplementary material with the online version of this paper. laboratory has been isolating actinomycete strains from different Brazilian soils for many years and selecting those which have shown significant enzyme production and therefore biotechnological potential (Coelho \& Drozdowicz, 1978; Gomes et al., 2000a, b; Nascimento et al., 2003; Semêdo et al., 2004). Strain RCQ $1071^{\mathrm{T}}$ was isolated from an acid orthic ferralsol from central Brazil, under cerrado vegetation, and was selected for further study because of its chitinolytic activity detected on colloidal chitin agar medium (Gomes et al., 2001). When utilizing glycol chitin as a substrate, this isolate exhibited high endochitinase activity at $40{ }^{\circ} \mathrm{C}$ and $\mathrm{pH}$ 8.0. Purified enzyme was stable at temperatures up to $70{ }^{\circ} \mathrm{C}$ and $\mathrm{pH}$ 4.0-9.0. Broad-range enzyme stability is promising for biotechnological purposes, specifically the degradation of chitin-containing waste (Sakai et al., 1998). The purified endochitinase also showed antifungal activity when tested against seven phytopathogenic fungi (Gomes et al., 2001), suggesting that strain RCQ $1071^{\mathrm{T}}$ has potential in the biological control of plant fungal pathogens.

Preliminary taxonomic characterization, based on analysis of morphological features (aerial hyphae with spiral spore 
chains) and chemotaxonomic data (presence of LLdiaminopimelic acid and the absence of a diagnostic cellwall sugar, which characterizes it as cell-wall chemotype I sensu Lechevalier \& Lechevalier, 1970) revealed that the strain belonged to the genus Streptomyces (Gomes et al., 2001). Numerical taxonomic analysis was performed according to Williams et al. (1983a). Seventy-five tests (see Supplementary Table S1 in IJSEM Online) were performed and the results were compared with those of other streptomycetes by using the program PIBwin version 1.9.2 (Bryant, 2004). Strain RCQ1071 $1^{\mathrm{T}}$ did not cluster with described groups within the identification matrix. Chain morphology and spore ornamentation were examined by light and transmission electron microscopy (EM 900; Zeiss) after 14 days of growth on malt extract/yeast extract agar (Shirling \& Gottlieb, 1966). Aerial spore-mass colour, substrate mycelial pigmentation and production of diffusible pigments were recorded after incubation at $28{ }^{\circ} \mathrm{C}$ for 14 days on inorganic salts/starch agar and glycerol/ asparagine agar (Shirling \& Gottlieb, 1966). Melanin production was tested on tyrosine agar medium and peptone/yeast extract/iron agar (Shirling \& Gottlieb, 1966).

The ability of strain RCQ $1071^{\mathrm{T}}$ to grow in the presence of $\left(\mu \mathrm{g} \mathrm{ml}^{-1}\right.$ unless indicated) neomycin sulfate (50), oleandomycin (100), penicillin $\mathrm{G}$ sodium salt $\left(10 \mathrm{IU} \mathrm{ml}^{-1}\right)$, rifampicin (50), streptomycin sulfate (100), gentamicin sulfate (100), dimethylchlortetracycline (500), novobiocin (100), methacyclin hydrochloride (100), ampicillin sodium salt (100) and cycloheximide (100) was tested by incubation at $28{ }^{\circ} \mathrm{C}$ for 7 days on plates containing modified Bennett's agar (MBA), with glucose replaced by glycerol. Similarly, strain RCQ $1071^{\mathrm{T}}$ was examined to test its ability to grow on MBA supplemented with $(\%, w / v)$ phenol $(0.1)$, potassium tellurite $(0.001)$, sodium chloride (7) and sodium azide (0.01) and to grow at $45^{\circ} \mathrm{C}$. Antimicrobial activity of strain RCQ $1071^{\mathrm{T}}$ was tested against Aspergillus niger LIV 131, Micrococcus luteus NCIB 196, Streptomyces murinus ISP 5091, Bacillus subtilis NCIB 3610 and Candida albicans CBS 562. All physiological and biochemical characteristics were determined according to Williams et al. (1983a); results that distinguished strain RCQ $1071^{\mathrm{T}}$ from its closest phylogenetic relatives are shown in Table 1.

Cell-wall amino acids were analysed after acid hydrolysis of the cell mass by using $6 \mathrm{M} \mathrm{HCl}$. Hydrolysed material was dried, suspended in the appropriate buffer and injected into an automatic analyser (High Performance Amino Acid Analyser, system 6300; Beckman), according to the manufacturer's instructions. Amino acids were identified automatically by comparison of retention times against a standard mixture. The major amino acids found in cellwall hydrolysates of strain RCQ $1071^{\mathrm{T}}$, in order of relative abundance, were alanine and glycine, followed by glutamic acid, leucine, threonine, methionine and lysine, which are consistent with patterns obtained for amino acid analysis of another streptomycete isolated from Brazilian soil (Semêdo et al., 2004).
Table 1. Differential physiological and biochemical properties between strain RCQ $1071^{\top}$ and its closest relatives

Strains: 1 , RCQ $1071^{\mathrm{T}}$; 2, S. albulus DSM $40492^{\mathrm{T}}$; 3, S. noursei ATCC $11455^{\mathrm{T}}$; 4, S. yunnanensis DSM $41793^{\mathrm{T}}$. Data for reference strains were obtained in this study.

\begin{tabular}{|c|c|c|c|c|}
\hline Characteristic & 1 & 2 & 3 & 4 \\
\hline Spore-mass colour ${ }^{\star}$ & G & $\mathrm{G} / \mathrm{R}$ & G & LGB/PY \\
\hline Spore surface $\dagger$ & s & $\mathrm{s}$ & $\mathrm{s}$ & $\mathrm{R}$ \\
\hline \multicolumn{5}{|l|}{ Substrate mycelium colour on:* } \\
\hline Glycerol-asparagine agar & YB & - & - & LOY \\
\hline Inorganic salts-starch agar & YB & - & - & LGY \\
\hline $\begin{array}{l}\text { Diffusible pigment production on } \\
\text { glycerol-asparagine agar* }\end{array}$ & - & - & - & LY \\
\hline \multicolumn{5}{|l|}{ Degradation of: } \\
\hline Allantoin & + & - & - & + \\
\hline Guanine & - & + & - & - \\
\hline L-Tyrosine & + & - & + & + \\
\hline Urea & + & + & - & + \\
\hline Xanthine & - & + & - & - \\
\hline \multicolumn{5}{|l|}{ Growth on sole carbon source } \\
\hline D-Xylose & - & + & - & - \\
\hline L-Arabinose & + & + & - & + \\
\hline L-Rhamnose & + & - & - & + \\
\hline Raffinose & - & - & - & + \\
\hline Sucrose & + & - & + & - \\
\hline \multicolumn{5}{|l|}{ Growth in: } \\
\hline Sodium azide $(0.01 \%, \mathrm{w} / \mathrm{v})$ & + & - & + & + \\
\hline Sodium chloride $(7 \%, \mathrm{w} / \mathrm{v})$ & + & - & - & - \\
\hline \multicolumn{5}{|l|}{ Growth on sole nitrogen source } \\
\hline Amino- $n$-butyric acid & + & - & + & + \\
\hline L-Arginine & + & - & + & + \\
\hline L-Methionine & + & - & + & + \\
\hline
\end{tabular}

${ }^{*}$, Grey; LGB, light grey-brown; LGY, light grey-yellow; LOY, light orange-yellow; LY, light yellow; PY, pale yellow; R, red; YB, yellowish brown.

$\dagger \mathrm{R}$, Rugose; s, spiny.

Extraction of genomic DNA from strain RCQ1071 ${ }^{\mathrm{T}}$ was carried out as described by Rintala et al. (2001). PCR amplification of the 16S rRNA gene was carried out by using a Gene Amp PCR System 9700 (Applied Biosystems) thermocycler and primers as described by Edwards et al. (1989). Amplified fragments were purified and sequenced directly by using the PureLink PCR purification kit (Invitrogen) and an ABI Prism dye terminator cycle sequencing reaction kit (ABI Prism 310 Genetic Analyzer), respectively. The almost-complete $16 \mathrm{~S}$ rRNA gene sequence $(1480 \mathrm{nt})$ obtained was subjected to similarity searches against data online at the Ribosomal Database Project (RDP) (Maidak et al., 1997) and GenBank (BLASTN; Altschul et al., 1997). Sequences retrieved were aligned and edited to the same size (1420 bp) by using BioEdit version 7.0.4.1 (Hall, 1999). Phylogenetic analyses were conducted by using MEGA version 4 (Tamura et al., 2007). Evolutionary distances were generated with 
Kimura's two-parameter model (Kimura, 1980) and the maximum-likelihood model (Felsenstein, 1981), and trees were constructed by using neighbour-joining (Saitou \& Nei, 1987). The type strains of Streptomyces melanosporofaciens and Streptomyces violaceusniger were used as an outgroup in phylogenetic reconstructions. Phylogenetic inferences depicted as phylograms/trees were subjected to bootstrap analysis based on 5000 resamplings in order to gain a measure of internal branch order and stability.

Based on 16S rRNA gene sequence similarities, strain RCQ $1071^{\mathrm{T}}$ was related most closely to Streptomyces yunnanensis YIM $41004^{\mathrm{T}}(97.97 \%)$, Streptomyces albulus NBRC $13410^{\mathrm{T}}(97.83 \%)$, Streptomyces noursei NBRC $15452^{\mathrm{T}}(97.83 \%)$ and Streptomyces viridis NBRC $13373^{\mathrm{T}}$ $(97.76 \%)$. Although the 16S rRNA gene sequence of strain RCQ $1071^{\mathrm{T}}$ was most similar to that from S. yunnanensis DSM $41793^{\mathrm{T}}$, strain $\mathrm{RCQ} 1071^{\mathrm{T}}$ formed a long branch separated from the above four species in the neighbourjoining tree (Fig. 1).

Genomic DNA-DNA hybridization experiments were performed to compare strain RCQ $1071^{\mathrm{T}}$ with its closest relatives as determined based on 16S rRNA gene sequences. Levels of genomic DNA-DNA relatedness were determined at the Deutsche Sammlung von Mikroorganismen und Zellkulturen GmbH (DSMZ). DNA was isolated by using a French pressure cell (Thermo Spectronic) and purified by chromatography on hydroxyapatite as described by
Cashion et al. (1977). DNA-DNA hybridization was carried out as described by De Ley et al. (1970) with the modifications described by Huß et al. (1983) by using a model Cary 100 Bio UV/Vis spectrophotometer equipped with a Peltier-thermostatted $6 \times 6$ multicell changer and a temperature controller with in-situ temperature probe (Varian). Strain $\mathrm{RCQ} 1071^{\mathrm{T}}$ shared $38.3,27.8$ and $46 \%$ DNA-DNA relatedness with $S$. albulus DSM $40492^{\mathrm{T}}, S$. noursei DSM $40635^{\mathrm{T}}$ and S. yunnanensis DSM $41793^{\mathrm{T}}$, respectively. These results clearly demonstrate that strain RCQ $1071^{\mathrm{T}}$ does not belong to one of the species seen in the $16 \mathrm{~S}$ rRNA gene sequencing clusters, as values were well below the $70 \%$ threshold recommended for the recognition of separate genomic species (Wayne et al., 1987).

Given that strain RCQ $1071^{\mathrm{T}}$ showed high chitinase activity (Gomes et al., 2001), the most similar 16S rRNA gene sequences from the type strains of chitinolytic streptomycetes were also included in our analyses. Phylogenetic trees placed almost all chitinolytic streptomycetes in a unique clade, separated from strain RCQ1071 ${ }^{\mathrm{T}}$ (Fig. 1; see strains from Streptomyces thermoviolaceus to Streptomyces halstedii). Analyses of 16S rRNA gene sequences demonstrated that strain RCQ $1071^{\mathrm{T}}$ is phylogenetically distinct from the most similar type strains that exhibit chitinolytic activity. Phenotypic comparisons amongst these strains with strain RCQ1071 ${ }^{\mathrm{T}}$ (Table 1) highlight its uniqueness and support its recognition as representing a novel species. In conclusion, chitinolytic strain RCQ $1071^{\mathrm{T}}$, isolated from

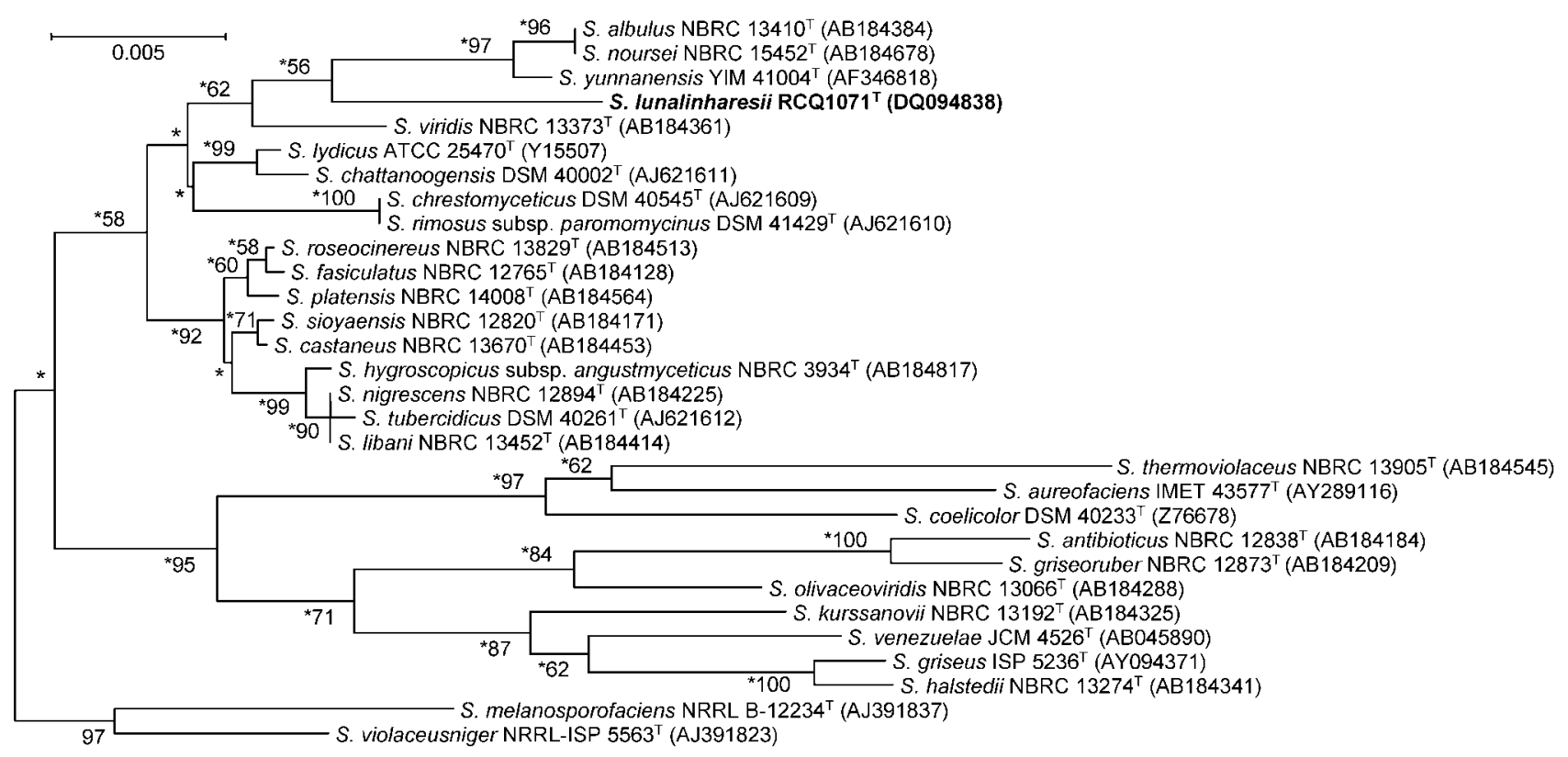

Fig. 1. Neighbour-joining tree (Saitou \& Nei, 1987) showing the phylogenetic relationships between strain RCQ $1071^{\top}$ and related streptomycetes. The phylogeny is based on an alignment of 1408 bases of the 16S rRNA gene sequence. Asterisks indicate branches that were also recovered by using the Kimura (1980) and maximum-likelihood (Felsenstein, 1981) models. Sequence accession numbers are shown in parentheses. Streptomyces melanosporofaciens NRRL B-12234 ${ }^{\top}$ and Streptomyces violaceusniger NRRL-ISP $5563^{\top}$ were used as the outgroup. Numbers at branch nodes indicate percentage bootstrap values based on 5000 resamplings; only values above $50 \%$ are shown. Bar, 0.005 substitutions per nucleotide position. 
an acid orthic ferralsol from central Brazil under cerrado vegetation, is clearly distinct from other phylogenetically and phenotypically related recognized Streptomyces species and thus represents a novel species. Based on the above we propose that this important chitinolytic strain, RCQ1071 ${ }^{\mathrm{T}}$, be formally recognized as the type strain of a novel species of the genus Streptomyces, for which the name Streptomyces lunalinharesii sp. nov. is proposed.

\section{Description of Streptomyces lunalinharesii sp. nov.}

Streptomyces lunalinharesii (lu'na.lin.ha're.si.i. N.L. masc. gen. n. lunalinharesii of Luna Linhares, named after Luiz Fernando de Toledo Luna Linhares, a Brazilian soil microbiologist).

An aerobic, Gram-positive, chitinolytic actinomycete that forms a grey-coloured aerial mycelium and yellow-brown substrate mycelium and presents spiny spores in spiral chains. The colour of the substrate mycelium is not $\mathrm{pH}$ sensitive and results from the production of a yellowbrown diffusible pigment the colour of which is also not $\mathrm{pH}$-sensitive. Cell-wall hydrolysates contain LL-diaminopimelic acid. The predominant amino acids in the cell-wall hydrolysate are alanine and glycine, followed by glutamic acid, leucine, threonine, methionine and lysine. Very good growth occurs on yeast extract/malt extract agar and on modified Bennett's agar. Antimicrobial activity is exhibited against Aspergillus niger and Candida albicans but is not observed against Kocuria rhizophila, Streptomyces murinus, Bacillus subtilis or Saccharomyces cerevisiae. Resistant to novobiocin, methacyclin hydrochloride, ampicillin sodium salt, cycloheximide, streptomycin sulfate (all at $100 \mu \mathrm{g}$ $\mathrm{ml}^{-1}$ ) and penicillin $\mathrm{G}$ sodium salt $\left(10 \mathrm{IU} \mathrm{ml}^{-1}\right)$ and degrades keratin, L-tyrosine, hypoxanthine, allantoin, casein, elastin, gelatin and starch. The species description is based on a single strain and hence serves as the type strain description.

The type strain, RCQ1071 ${ }^{\mathrm{T}}$ (=ATCC BAA- $1231^{\mathrm{T}}=\mathrm{CIP}$ $108852^{\mathrm{T}}=\mathrm{DSM} 41876^{\mathrm{T}}$ ), was isolated from an acid orthic ferralsol from central Brazil under cerrado vegetation.

\section{Acknowledgements}

We thank Dr Alan Ward for his valuable feedback and encouragement. This work was supported by grants from the Conselho Nacional de Desenvolvimento Científico e Tecnológico (CNPq), Coordenação de Aperfeiçoamento de Pessoal do Ensino Superior (CAPES), Fundação de Amparo à Pesquisa do Rio de Janeiro (FAPERJ), Financiadora de Estudos e Projetos (FINEP), Programa Nacional de Excelência (PRONEX, CNPq) and Fundação Universitária José Bonifácio (FUJB-UFRJ).

\section{References}

Altschul, S. F., Madden, T. L., Schaffer, A. A., Zhang, J., Zhang, Z., Miller, W. \& Lipman, D. J. (1997). Gapped BLAST and PSI-BLAST: a new generation of protein database search programs. Nucleic Acids Res 25, 3389-3402.
Bryant, T. N. (2004). PIBWin - software for probabilistic identification. J Appl Microbiol 97, 1326-1327.

Cashion, P., Holder-Franklin, M. A., McCully, J. \& Franklin, M. (1977). A rapid method for the base ratio determination of bacterial DNA. Anal Biochem 81, 461-466.

Coelho, R. R. R. \& Drozdowicz, A. (1978). The occurrence of actinomycetes in a cerrado soil in Brazil. Rev Ecol Biol Sol 15, 459473.

De Ley, J., Cattoir, H. \& Reynaerts, A. (1970). The quantitative measurement of DNA hybridization from renaturation rates. Eur $J$ Biochem 12, 133-142.

Edwards, U., Rogal, T., Blocker, H., Emde, M. \& Bottger, E. C. (1989). Isolation and direct complete nucleotide determination of entire genes. Characterization of a gene coding for $16 \mathrm{~S}$ ribosomal RNA. Nucleic Acids Res 17, 7843-7853.

Felsenstein, J. (1981). Evolutionary trees from DNA sequences: a maximum likelihood approach. J Mol Evol 17, 368-376.

Gomes, R. C., Semêdo, L. T. A. S., Soares, R. M. A., Alviano, C. S., Linhares, L. F. \& Coelho, R. R. R. (2000a). Chitinolytic actinomycetes from a Brazilian tropical soil active against phytopathogenic fungi. World J Microbiol Biotechnol 16, 109-110.

Gomes, R. C., Semêdo, L. T. A. S., Soares, R. M. A., Alviano, C. S., Linhares, L. F. \& Coelho, R. R. R. (2000b). Chitinolytic activity of actinomycetes from a cerrado soil and their potential in biocontrol. Lett Appl Microbiol 30, 146-150.

Gomes, R. C., Semêdo, L. T. A. S., Soares, R. M. A., Linhares, L. F., Ulhoa, C. J., Alviano, C. S. \& Coelho, R. R. R. (2001). Purification of a thermostable endochitinase from Streptomyces RC1071 isolated from a cerrado soil and its antagonism against phytopathogenic fungi. $J$ Appl Microbiol 90, 653-661.

Goodfellow, M., Ferguson, E. V. \& Sanglier, J. J. (1992). Numerical classification and identification of Streptomyces species - a review. Gene 115, 225-233.

Hall, T. A. (1999). BioEdit: a user-friendly biological sequence alignment editor and analysis program for Windows 95/98/NT. Nucleic Acids Symp Ser 41, 95-98.

Huang, Y., Li, W., Wang, L., Lanoot, B., Vancanneyt, M., Rodriguez, C., Liu, Z., Swings, J. \& Goodfellow, M. (2004). Streptomyces glauciniger sp. nov., a novel mesophilic streptomycete isolated from soil in south China. Int J Syst Evol Microbiol 54, 2085-2089.

Huß, V. A. R., Festl, H. \& Schleifer, K. H. (1983). Studies on the spectrophotometric determination of DNA hybridization from renaturation rates. Syst Appl Microbiol 4, 184-192.

Kimura, M. (1980). A simple method for estimating evolutionary rates of base substitutions through comparative studies of nucleotide sequences. J Mol Evol 16, 111-120.

Lechevalier, M. P. \& Lechevalier, H. A. (1970). Chemical composition as a criterion in the classification of aerobic actinomycetes. Int J Syst Bacteriol 20, 435-443.

Maidak, B. L., Olsen, G. J., Larsen, N., Overbeek, R., McCaughey, M. J. \& Woese, C. R. (1997). The RDP (Ribosomal Database Project). Nucleic Acids Res 25, 109-111.

Nascimento, R. P., Marques, S., Alves, L., Gírio, F., Amaral-Collaço, M. T., Sacramento, D. R., Bon, E. P. S. \& Coelho, R. R. R. (2003). A novel strain of Streptomyces malaysiensis isolated from Brazilian soil produces high endo- $\beta$-1,4-xylanase titres. World $J$ Microbiol Biotechnol 19, 879-881.

Rintala, H., Nevalainem, A., Rökä, E. \& Suutari, M. (2001). PCR primers targeting the $16 \mathrm{~S}$ rDNA gene for the specific detection of streptomycetes. Mol Cell Probes 15, 337-347. 
Saitou, N. \& Nei, M. (1987). The neighbor-joining method: a new method for reconstructing phylogenetic trees. Mol Biol Evol 4, 406425.

Sakai, K., Yokota, A., Kurokawa, H., Wakayama, M. \& Moriguchi, M. (1998). Purification and characterization of three thermostable endochitinases of a noble Bacillus strain, $\mathrm{MH}-1$, isolated from chitin-containing compost. Appl Environ Microbiol 64, 33973402.

Semêdo, L. T. A., Gomes, R. C., Linhares, A. A., Duarte, G. F., Nascimento, R. P., Rosado, A. S., Margis-Pinheiro, M., Margis, R., Silva, K. R. A. \& other authors (2004). Streptomyces drozdowiczii sp. nov., a novel cellulolytic streptomycete from soil in Brazil. Int J Syst Evol Microbiol 54, 1323-1328.

Shirling, E. B. \& Gottlieb, D. (1966). Methods for characterization of Streptomyces species. Int J Syst Bacteriol 16, 313-340.
Tamura, K., Dudley, J., Nei, M. \& Kumar, S. (2007). MEGA4: molecular evolutionary genetics analysis (MEGA) software version 4.0. Mol Biol Evol 24, 1596-1599.

Wayne, L. G., Brenner, D. J., Colwell, R. R., Grimont, P. A. D., Kandler, O., Krichevsky, M. I., Moore, L. H., Moore, W. E. C., Murray, R. G. E. \& other authors (1987). International Committee on Systematic Bacteriology. Report of the ad hoc committee on reconciliation of approaches to bacterial systematics. Int J Syst Bacteriol 37, 463-464.

Williams, S. T., Goodfellow, M., Anderson, G., Wellington, E. M. H., Sneath, P. H. A. \& Sackin, M. J. (1983a). Numerical classification of Streptomyces and related genera. J Gen Microbiol 129, 1743-1813.

Williams, S. T., Goodfellow, M., Anderson, G., Wellington, E. M. H., Vickers, J. C., Alderson, G., Sneath, P. H. A., Sackin, M. J. \& Mortimer, A. M. (1983b). A probability matrix for identification of some streptomycetes. J Gen Microbiol 129, 1815-1830. 